\title{
Thermal behavior of direct resin composites: glass transition temperature and initial degradation analyses
}

\section{Comportamento térmico de resinas compostas de uso direto: temperatura de transição vítrea e temperatura de degradação inicial}

\begin{abstract}
Purpose: The association of direct resin composites with simple thermal treatments may improve the mechanical properties of these materials. However, the ideal temperature for heat application depends on the thermal behavior of each material, such as glass transition $\left(T_{g}\right)$ and initial degradation temperatures. To propose a heat treatment methodology, this study evaluated the thermal behavior of five commercial direct resin composites using differential scanning calorimetry (DSC) and thermogravimetric analysis (TGA).

Methods: Photo-irradiation was achieved in cylindrical specimens $(3 \times 2 \mathrm{~mm})$ using a photoactivator source $\left(600 \mathrm{~mW} / \mathrm{cm}^{2}\right.$ for $\left.40 \mathrm{~s}\right)$. Thermal analyses were performed by DSC and TGA using a temperature range from $25^{\circ} \mathrm{C}$ to $900^{\circ} \mathrm{C}$.

Results: $\mathrm{T}_{\mathrm{g}}$ values obtained by DSC were $130.6^{\circ} \mathrm{C}$ for FillMagic, $129^{\circ} \mathrm{C}$ for Glacier, $143.5^{\circ} \mathrm{C}$ for Te-Econom, $147.5^{\circ} \mathrm{C}$ for Prisma APH and $143.7^{\circ} \mathrm{C}$ for Natural Look. A moderate weight loss began at around $270^{\circ} \mathrm{C}$ for all materials, which represented the initial degradation temperature.

Conclusion: Regarding the heat treatment itself, it was concluded that the effective temperature for heat treatment is material dependent.
\end{abstract}

Key words: Dental composite; thermal treatment; DSC; TGA

\section{Resumo}

Objetivo: A associação de resinas compostas de uso direto com tratamentos térmicos pode melhorar as propriedades mecânicas destes materiais. No entanto, a temperatura ideal de aplicação está na dependência do comportamento térmico individual, como a temperatura de transição vítrea $\left(T_{\rho}\right)$ e a temperatura inicial de degradação. Com o objetivo de propor uma metodologia de aplicação do tratamento térmico, o objetivo deste trabalho foi caracterizar cinco resinas compostas de uso direto usando calorimetria exploratória diferencial (DSC) e termogravimetria (TGA).

Metodologia: Corpos-de-prova cilíndricos $(3 \times 2 \mathrm{~mm})$ foram fotoirradiados utilizando um aparelho de fotopolimerização $\left(600 \mathrm{~mW} / \mathrm{cm}^{2}-40 \mathrm{~s}\right)$. As análises térmicas foram realizadas nas temperaturas de $25^{\circ} \mathrm{C}$ a $900^{\circ} \mathrm{C}$.

Resultados: Os valores de $\mathrm{T}_{\mathrm{g}}$ após análise de DSC foram: $130,6^{\circ} \mathrm{C}$ para FillMagic, $129^{\circ} \mathrm{C}$ para Glacier, $143,5^{\circ} \mathrm{C}$ para Te-Econom, $147,5^{\circ} \mathrm{C}$ para Prisma APH e $143,7^{\circ} \mathrm{C}$ para Natural Look. Para todos os materiais estudados a degradação iniciou-se por volta de $270^{\circ} \mathrm{C}$.

Conclusão: Considerando a aplicação do tratamento térmico em resinas compostas de uso direto, é possível sugerir que a temperatura efetiva é dependente do material em uso.

Palavras-chave: Resina composta; tratamento térmico; DSC; TGA

\author{
Ivone Lima Santana a \\ Letícia Machado Gonçalves b \\ Jacqueline Jady Soares Ribeiro a \\ Joaquim Rodrigues Mochel Filho a \\ Aluísio Alves Cabral Júnior c
}

a Department of Odontology I, Federal University of Maranhão, São Luís, MA, Brazil

b Department of Prosthodontics and Periodontology, Piracicaba Dental School, State University of Campinas, Piracicaba, SP, Brazil

c Post-Graduation Section of Materials Engineering, Federal University of Maranhão, São Luís, MA, Brazil

\section{Correspondence:}

Letícia Machado Gonçalves

Departamento de Prótese e Periodontia

Faculdade de Odontologia de Piracicaba

Universidade Estadual de Campinas

Avenida Limeira, 901

Piracicaba, SP - Brazil

$13414-903$

E-mail: lets.mg@gmail.com

Received: August 10, 2010

Accepted: December 6, 2010

Conflict of Interest Statement: The authors state that there are no financial and personal conflicts of interest that could have inappropriately influenced their work.

Copyright: (C) 2011 Santana et al.; licensee EDIPUCRS. This is an Open Access article distributed under the terms of the Creative Commons AttributionNoncommercial-No Derivative Works 3.0 Unported License. 


\section{Introduction}

Since direct resin composites were developed as an aesthetic and more conservative alternative to silver amalgams, many efforts have been made to increase the longevity of dental restorations. Although several improvements have been made, mechanical properties such as wear, fracture resistance and hardness are challenged by chewing forces and microleakage caused by polymerization contraction stress (1).

One possible way to minimize the problems related to microleakage and polymerization stress is to use aesthetic indirect composite bonded restorations instead of direct composites (2). In the indirect technique, specific resin systems are applied to the damaged tooth area to form a cast restoration that is then heat-treated using special ovens under controlled laboratory conditions $(3,4)$. The heat treatment improves mechanical properties and contributes to the relief of stresses that originate during the resin polymerization and finishing procedures (4-6). However, the disadvantage of this technique is the high cost, because special equipment are required for the laboratory process $(3,7,8)$, and the increase in the number of required appointments.

Direct resins and resin systems for indirect use display similar compositions $(9,10)$. Therefore, many authors have proposed that the association of direct composites with simple thermal treatments may produce similar results when compared to the indirect technique, such as the improvement in material cure, thus enhancing clinical and mechanical properties (9-14). An advantage would be the lower cost because the special ovens could be replaced by other heat sources, such as cast furnaces or auto-claves (13), which are commonly available in a prosthetic laboratory and dental offices.

However, the ideal temperature for heat treatment application depends on the thermal behavior of each composite, such as glass transition temperature analysis $\left(T_{g}\right)$ and initial degradation temperature (14). The $T_{g}$ can successfully be used as a reference to sign the ideal heat treatment for photo-irradiated resin composites. Above $\mathrm{T}_{\mathrm{g}}$, the secondary molecular interactions are weakened and, as a consequence, material properties are optimized once trapped radicals are given the opportunity to react $(7,15)$. In addition, the maximum temperature for heating without damaging, i.e., initial degradation temperature, needs to be determined to avoid weight loss $(13,14)$.

Thermal analysis techniques using differential scanning calorimetry (DSC) and thermogravimetric analysis (TGA) are suitable for examining the characteristics of polymers $(6,13,14,16-18)$. DSC techniques assess the energy (enthalpy) absorbed or released by a specimen during a temperature increase, decrease or even at isothermal conditions. With this method, it is possible to identify the critical temperature, such as $T_{g}$, for the analyzed material. TGA is a precise quantitative method for determining combustion, volatilization and decomposition by analyzing weight alterations (gain or loss) of a specimen as a function of temperature and/or time (13).

The objective of our research group has been to study the clinical performance of different heat-treated direct resin composites. However, the determination of specific critical temperatures for each composite studied was still not a focus. To propose a heat treatment methodology, this work examined the thermal behavior of various commercial direct resin composites using DSC and TGA analysis.

\section{Methods}

Five commercial direct resin composites were evaluated. Technical specifications of the materials are listed in Table 1.

Table 1. Technical specifications of direct resin composites according to the suppliers.

\begin{tabular}{|c|c|c|c|c|c|}
\hline \multirow{2}{*}{ Composite } & \multirow{2}{*}{ Manufacturer } & \multirow{2}{*}{ Characteristic } & \multicolumn{2}{|c|}{ Composition } & \multirow{2}{*}{ Batch $\mathrm{n}$. } \\
\hline & & & Organic Matrix* & Filler & \\
\hline FillMagic & $\begin{array}{l}\text { Vigodent S.A. Ind. Com. } \\
\text { Bonsucesso, RJ, Brazil }\end{array}$ & $\begin{array}{l}\text { Micro-hybrid } \\
\text { composite }\end{array}$ & $\begin{array}{l}\text { bis-GMA, bis-EMA, } \\
\text { TEGDMA and } \\
\text { UDMA }\end{array}$ & $\begin{array}{l}\text { Barium and aluminum } \\
\text { silicate glass and pyrogenic } \\
\text { silicon }(0.5 \mu \mathrm{m}) .80 \% \text { wt. }\end{array}$ & $129 / 08$ \\
\hline Glacier & $\begin{array}{c}\text { SDI Limited Bayswater, } \\
\text { Victoria, Australia }\end{array}$ & $\begin{array}{l}\text { Condensable } \\
\text { micro-hybrid } \\
\text { composite }\end{array}$ & $\begin{array}{l}\text { Multifunctional } \\
\text { methacrylic ester }\end{array}$ & $\begin{array}{l}\text { Strontium glass and } \\
\text { amorphous silica } \\
(0.4-1.0 \mu \mathrm{m}) .81 \% \text { wt. }\end{array}$ & 07/0507 \\
\hline TE-Econom & $\begin{array}{l}\text { Ivoclar Vivadent, } \\
\text { Schaan, Liechtenstein }\end{array}$ & Hybrid composite & $\begin{array}{l}\text { bis-GMA, TEGDMA } \\
\text { and UDMA }\end{array}$ & $\begin{array}{l}\text { Barium glass, aluminum } \\
\text { and barium fluorosilicate } \\
\text { glass, high/dispersed silicon } \\
\text { dioxide and mutual spheroid } \\
\text { oxides }(1.0 \mu \mathrm{m}) .72 \% \text { wt. }\end{array}$ & 16366 \\
\hline Natural Look & DFL Ind. Com, RJ, Brazil & $\begin{array}{l}\text { Micro-hybrid } \\
\text { composite }\end{array}$ & $\begin{array}{l}\text { bis-GMA } \\
\text { bis-EMA } \\
\text { TEGDMA }\end{array}$ & $\begin{array}{c}\text { Barium crystal glass and } \\
\text { amorphous silica }(0.5 \mu \mathrm{m}) \text {. } \\
77 \% \text { wt }\end{array}$ & 08050692 \\
\hline Prisma APH & $\begin{array}{l}\text { Dentsply Ind. Com. } \\
\text { Petrópolis, RJ, Brazil }\end{array}$ & Hybrid composite & Modified urethane & $\begin{array}{l}\text { Barium and aluminum } \\
\text { silicate, silanized barium, } \\
\text { pyrogenic silicon (1.0 } \mu \mathrm{m}) \text {. }\end{array}$ & $091391 \mathrm{~B}$ \\
\hline
\end{tabular}




\section{Specimen preparation}

Specimens were prepared in a cylindrical mould with a $3 \mathrm{~mm}$ diameter and a $2 \mathrm{~mm}$ height; there were thirty specimens in each one. The mould was positioned over a polyester film (Mylar, Labordental Ltda., São Paulo, SP, Brazil) lying over a glass slab. A single bulk of each resin composite was inserted into the mould and then covered with another piece of Mylar film. To standardize composite thickness, a glass slide was pressed over the film allow excess material extrusion from the mould. After excess removal, the upper surface was irradiated for $40 \mathrm{~s}$ using a $600 \mathrm{~mW} / \mathrm{cm}^{2}$ photoactivator source (Ultraled, Dabi Atlante, Ribeirão Preto, SP, Brazil) with a $12 \mathrm{~mm}$ diameter tip that was in contact with the Mylar film. The device irradiance was measured by a radiometer (serial \#111231, Demetron Research Danbury, CT, USA). The irradiated face of each specimen was then identified using a permanent marker. After being removed from the mould, specimens were submitted to finishing with a number 15 scalpel (Lamedid Comercial e Serviços Ltda., Barueri, SP, Brazil). Immediately after the specimen preparation, specimens were stored in dark boxes at $37^{\circ} \mathrm{C}$ for $24 \mathrm{~h}$.

\section{DSC and TGA analyses}

Thermal analyses were simultaneously performed by differential scanning calorimetry (DSC) and thermogravimetric analysis (TGA) using a single device (STA Jupiter 449 , Netzch, Brazil). Temperatures ranged from $25^{\circ} \mathrm{C}$ to $900^{\circ} \mathrm{C}$ under high purity argon atmosphere $(20 \mathrm{~mL} / \mathrm{min})$ and were at a heating rate of $10^{\circ} \mathrm{C} \mathrm{min}-1$ using ceramic crucibles. The equipment was calibrated with barium carbonate $\left(\mathrm{BaCO}_{3}\right)$, cesium chloride $(\mathrm{CsCl})$, potassium chromate IV $\left(\mathrm{K}_{2} \mathrm{CrO}_{4}\right)$ rubidium nitrate $\left(\mathrm{RbNO}_{3}\right)$ and benzoic acid $\left(\mathrm{C}_{6} \mathrm{H}_{5} \mathrm{COOH}\right)$ as standards. For both tests, curves were obtained with empty crucibles in the same experimental conditions of the tests (baseline). Those baselines were used to correct the thermo analytical curves of the samples. Descriptive statistics were calculated using the BIOESTAT 5.0 program.

\section{Results}

In Figures 1 through 5, representative derivative curves were calculated to assist the identification of the thermal events of each direct resin composite. Mean values and standard deviations for $\mathrm{T}_{\mathrm{g}}$ and degradation temperatures are represented in Table 2 . The $\mathrm{T}_{\mathrm{g}}$ values obtained by DSC analyses were $130.6^{\circ} \mathrm{C}$ for FillMagic, $129^{\circ} \mathrm{C}$ for Glacier, $143.5^{\circ} \mathrm{C}$ for Te-Econom, $147.5^{\circ} \mathrm{C}$ for Prisma APH and $143.7^{\circ} \mathrm{C}$ for Natural Look. TGA revealed that the weight loss and consequent initial degradation for all resin specimens occur in steps. For temperatures above $270^{\circ} \mathrm{C}$, there was a significant weight loss, which may have been due to the unreacted monomer volatilization or other degradation processes.

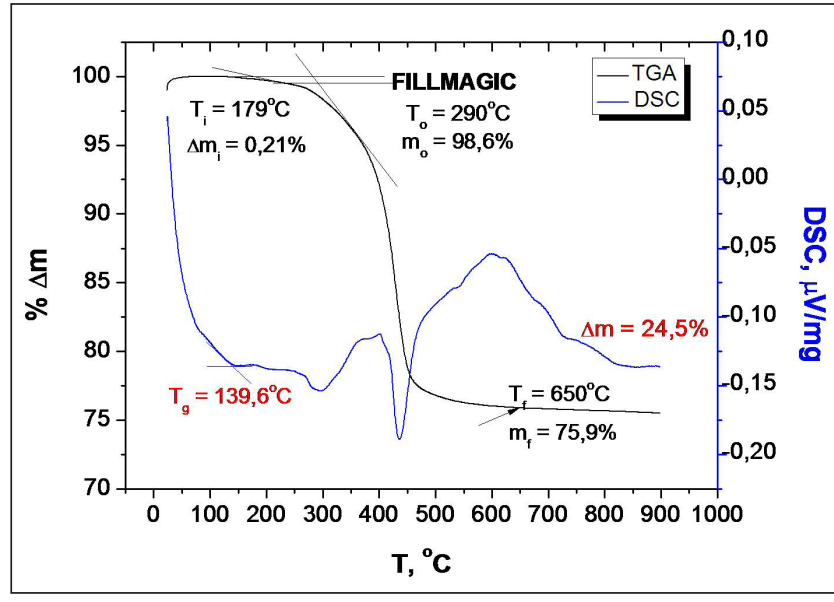

Fig. 1. Representative thermogravimetric and derivate curves for FillMagic.

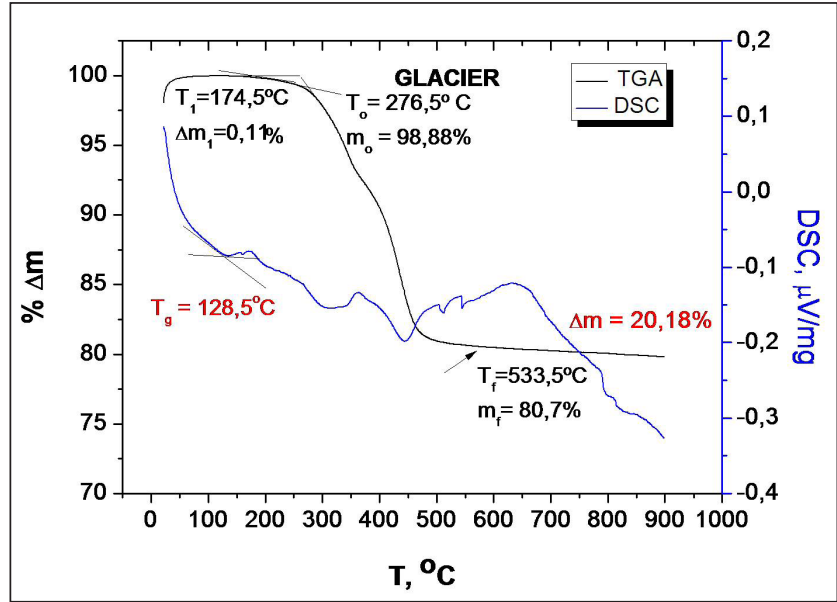

Fig. 2. Representative thermogravimetric and derivate curves for Glacier.

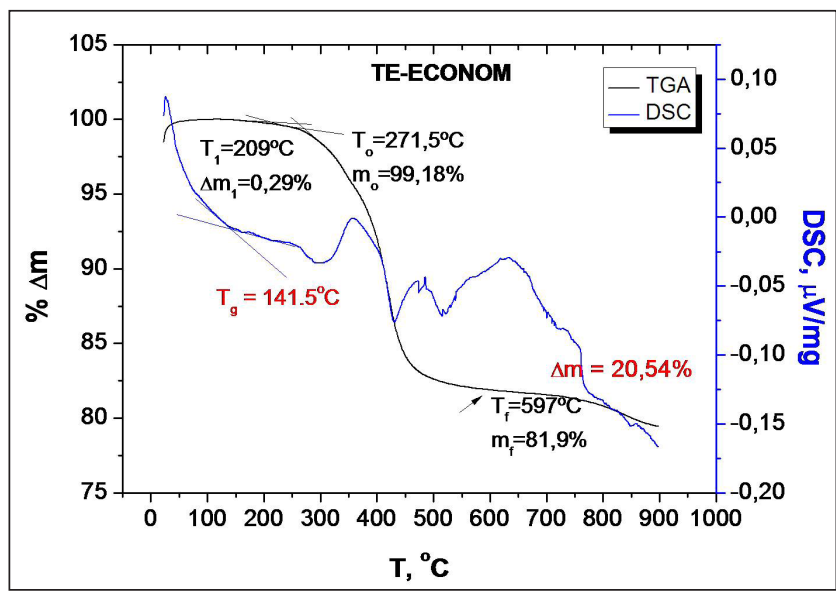

Fig. 3. Representative thermogravimetric and derivate curves for Te-Econom. 


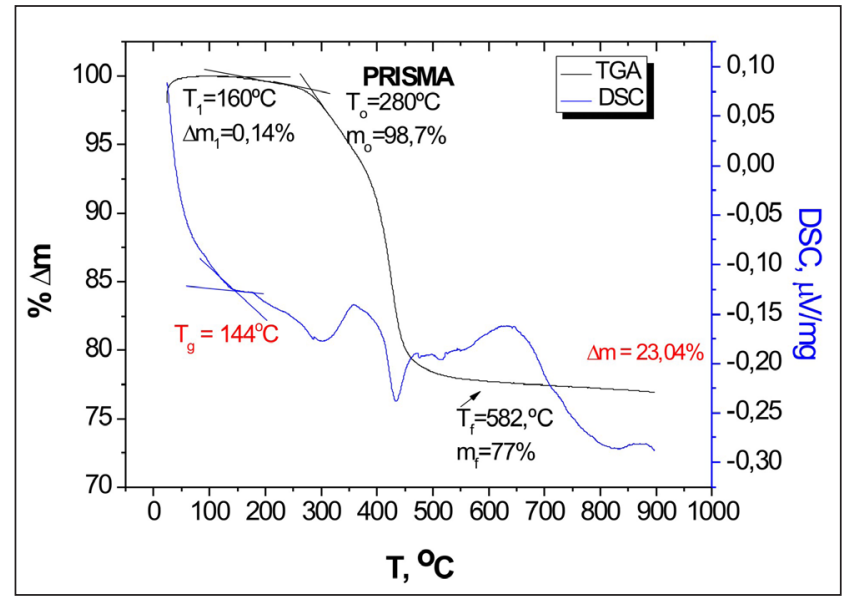

Fig. 4. Representative thermogravimetric and derivate curves for Prisma APH.

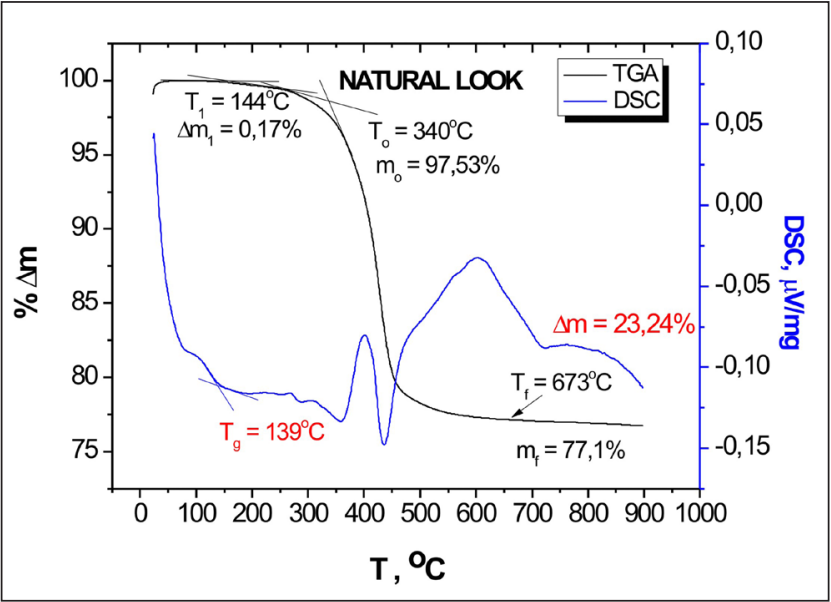

Fig. 5. Representative thermogravimetric and derivate curves for Natural Look.

Table 2. Mean and standard deviations of glass transition temperature $(\mathrm{Tg})$ and degradation temperature.

\begin{tabular}{lcc}
\hline \multicolumn{1}{c}{ Composite } & $\begin{array}{c}\text { Glass transition } \\
\text { temperature }(\mathrm{Tg})\end{array}$ & $\begin{array}{c}\text { Degradation } \\
\text { temperature }\end{array}$ \\
\hline FillMagic & $130.6^{\circ} \mathrm{C} \pm 11.1$ & $293.8^{\circ} \mathrm{C} \pm 12.9$ \\
Glacier & $129.0^{\circ} \mathrm{C} \pm 5.5$ & $277.3^{\circ} \mathrm{C} \pm 6.3$ \\
Te-Econom & $143.5^{\circ} \mathrm{C} \pm 5.0$ & $275.8^{\circ} \mathrm{C} \pm 8.3$ \\
Prisma APH & $147.5^{\circ} \mathrm{C} \pm 11.4$ & $282.5^{\circ} \mathrm{C} \pm 9.7$ \\
Natural Look & $143.7^{\circ} \mathrm{C} \pm 12.9$ & $344.7^{\circ} \mathrm{C} \pm 8.0$ \\
\hline
\end{tabular}

\section{Discussion}

DSC is a technique that, by energy variation, measures the temperature difference between the sample and a reference at a temperature controlled program. With this method, it is possible to identify the critical temperatures for the analyzed material, which allows for the observation of thermal events in ceramics, glass or polymers (e.g., crystallization, melt, $\mathrm{T}_{\mathrm{g}}$ ). $\mathrm{T}_{\mathrm{g}}$ refers to the temperature of each material in which there is an increase in the coefficient of linear thermal expansion (CLTE) and a reduction in viscosity and the elastic modulus $(13,14)$. This temperature can be used as a reference point to design the ideal heat treatment. Above Tg, the degree of conversion can increase once the monomers are given further opportunity to react $(7,15)$. However, the $T_{g}$ of direct composites varies, among other aspects, as a function of composition (monomer blend, filler type and concentration) and crosslink density (which depends on the degree of conversion/polymerization, etc.) (19).

All results for DSC obtained in this study were higher than the values obtained by previous studies for other direct resin composites, which report values ranging from 35 to $120^{\circ} \mathrm{C}$ $(6,9,10,15,20,21)$. This large difference derives from many reasons, such as different materials (experimental composites with or without filler, commercial composites, matrix resin), techniques (DSC, thermo-mechanical analysis), atmosphere conditions (air, nitrogen, vacuum), heating rate, resin mass, etc. $(15,19,20)$. In fact, the $T_{g}$ values found in this study are a function of the methodology employed (photoactivation mode, specimen thickness, etc.).

With TGA it is possible to determine, by mass alteration, the thermal degradation of a material (6). In this study, this test sought to determine the maximum secure temperature in which it is possible to submit direct resin composites without the occurrence of marked degradation of the components. TGA revealed that the weight loss and consequent degradation for all resin composites studied began around $270^{\circ} \mathrm{C}$ and this process occur in steps, similar to the results of other studies (16-18).

In addition, some authors use TGA to compare the filler loading in dental composites as stated by the manufacturer with the experimental results obtained $(16,22,23)$.

The results for FillMagic suggested that an initial weight loss up to $1,4 \%$ began around $293.8^{\circ} \mathrm{C}$. Above $650^{\circ} \mathrm{C}$, the mass tended to stabilize, corresponding to the inorganic fraction of the resin (Fig. 1). In this study, FillMagic was $75.5 \% \mathrm{wt}$, which is not in agreement with the values stated by the manufacturer $(80 \% \mathrm{wt})$.

Initial degradation of Glacier was observed around $277.3^{\circ} \mathrm{C}$, which presented a weight loss up to $1.12 \%$. Above $533.5^{\circ} \mathrm{C}$, an inert residue of $79.82 \%$ was left, which corresponded to the inorganic fraction (Fig. 2). The high content of inorganic filler confirmed that its value is very close to the figure given by the supplier $(81 \% \mathrm{wt})$.

A moderate weight loss began around $275.8{ }^{\circ} \mathrm{C}$ for Te-Econom. Between 275.8 and $500^{\circ} \mathrm{C}$, weight loss reached $16.58 \%$ and became $20.54 \%$ at $900{ }^{\circ} \mathrm{C}$. After mass stabilization, we observed an inorganic content of $74.96 \%$, which is not in agreement with the values given by the manufacturer (72\% wt) (Fig. 3).

A moderate weight loss began around $282.5^{\circ} \mathrm{C}$ for Prisma APH. Between 282.5 and $580^{\circ} \mathrm{C}$ we detected the highest 
mass degradation. After mass stabilization, we observed an inorganic content of $76.96 \%$ (Fig. 5). This data could not be compared because they were not reported by the manufacturer.

For Natural Look, initial degradation was observed around $344.7^{\circ} \mathrm{C}$, which presented a weight loss up to $2.47 \%$. Above $500^{\circ} \mathrm{C}$, an inert residue of $76.76 \%$ was left that corresponded to the inorganic fraction (Fig. 4). This content of inorganic filler was very close to the figure given by the manufacturer $(77 \% \mathrm{wt})$.

Several factors, such as differences in the organic matrix composition (5), type and content of the inorganic filler $(9,10)$ may be the basis to explain the results for each material. Differences in organic matrix, such as the type of monomers and the photoinitiators present, might play a role in the observed results. Variations among monomers from different resins result in distinct hydrophilic properties, different degrees of conversion and different capacities to form crossed chains during polymerization (18). Little variation in the organic matrix composition among the assessed resins can be observed, with the exception of Glacier. This resin has ester-methacrylic acid, a lowmolecular-weight monomer, which probably negatively affects $T_{g}$ values because, as a general rule, it is accepted that the lower the mean molecular weight of the monomer, the lower the boiling temperature and the greater the percentage of shrinkage (13). Furthermore, differences in the amount of filler loading among the resins studied have been directly related to the $\mathrm{T}_{\mathrm{g}}$. The greater the percentage of filler loading, the higher the polymer structure homogeneity and, therefore, the higher the $\mathrm{T}_{\mathrm{g}}(13,14)$.

\section{Conclusions}

The association of direct resin composites with simple heat treatments could be an alternative to the expensive current indirect composite systems. Regarding the heat treatment itself, it was assumed that the effective temperature for heat treatment is material dependent. In addition, this study has clinical relevance considering that we revealed the maximum secure temperature in which it is possible to submit five commercial direct resin composites without the occurrence of marked degradation of the components. Despite these results, more studies are needed to assess the thermal behavior of other resins due to the wide variety of aesthetic materials on the market. Dent Mater 1993;9:325-31.

2. Lovell LG, Lu H, Elliott JE, Stansbury JW, Bowman CN. The effect of cure rate on the mechanical properties of dental resins. Dent Mater 2001;17:504-11.

3. Terry DA, Touati B. Clinical considerations for aesthetic laboratory-fabricated inlay/onlay restorations: a review. Pract Proced Aesthet Dent 2001;13:51-8.

4. Cesar PF, Miranda WG, Braga RR. Influence of shade and storage time on the flexural strength, flexural modulus, and hardness of composites used for indirect restorations. J Prosthet Dent 2001;86:289-96.

5. Peutzfeldt $A$, Asmussen E. The effect of postcuring on quantity of remaining double bonds, mechanical properties, and in vitro wear of two resin composites. J Dent 2000;28: 447-52.

6. Sideridou I, Achilias DS, Kyrikou E. Thermal expansion characteristics of light-cured dental resins and resin composites. Biomaterials 2004;25:3087-97.

7. Eldiwany M, Powers JM, George LA. Mechanical properties of direct and post-cured composites. Am J Dent 1993;6:222-4.

8. Cesar PF, Miranda WG, Braga RR. Influence of shade and storage time on the flexural strength, flexural modulus, and hardness of composites used for indirect restorations. J Prosthet Dent $2001 ; 86: 289-96$.

9. Wendt SL. The effect of heat used as a secondary cure upon the physical properties of three composite resins. I. Diametral tensile strength, compressive strength, and marginal dimensional stability. Quintessence Int 1987;18:265-71.

10. Wendt SL. The effect of heat used as secondary cure upon the physical properties of three composite resins. II. Wear, hardness, and color stability. Quintessence Int 1987; 18:351-6.

11. Bagis $\mathrm{YH}$, Rueggeberg FA. The effect of post-cure heating on residual, unreacted monomer in a commercial resin composite. Dent Mater 2000;16:244-7.

12. Loza-Herrero MA, Rueggeberg FA, Caughman WF, Schuster GS, Lefebvre CA, Gardner FM. Effect of heating delay on conversion and strength of a post-cured resin composite. J Dent Res 1998;77:426-31.

13. Santana IL, Lodovici E, Matos JR, Medeiros IS, Miyazaki CL, Rodrigues-Filho LE. Effect of experimental heat treatment on mechanical properties of resin composites. Braz Dent J 2009;20:205-10.

14. Miyazaki CL, Medeiros IS, Santana IL, Matos JDR, Rodrigues Filho LE. Heat treatment of a direct composite resin: influence on flexural strength. Braz Oral Res 2009;23:241-7. 
15. Vaidyanathan J, Vaidyanathan TK, Wang Y, Viswanadhan T. Thermoanalytical characterization of visible light cure dental composites. J Oral Rehabil 1992;19:49-64.

16. Mendes LC, Tedesco AD, Miranda MS, Benzi MR, Chagas BS. Determination of degree of conversion as a function of depth of a photo-initiated dental restoration composite--II application to commercial SureFil(TM). Polymer Testing 2005;24:942-6.

17. Mendes LC, Tedesco AD, Miranda MS, Benzi MR, Chagas BS. Determination of degree of conversion as a function of depth of a photo-initiated dental restoration composite--III application to commercial Prodigy Condensable(TM). Polymer Testing 2005;24:963-8.

18. Mendes LC, Tedesco AD, Miranda MS. Determination of degree of conversion as function of depth of a photo-initiated dental restoration composite. Polymer Testing 2005;24:41822.

19. Jancar J, Wang W, DiBenedetto AT. On the heterogeneous structure of thermally cured bis-GMA/TEGDMA resins. J Mater Sci Mater Med 2000;1 1:675-82.

20. Truffier-Boutry D, Demoustier-Champagne S, Devaux J, Biebuyck J, Mestdagh M, Larbanois $\mathrm{P}$ et al. A physico-chemical explanation of the post-polymerization shrinkage in dental resins. Dent Mater 2006;22:405-12.

21. Lovell LG, Lu H, Elliott JE, Stansbury JW, Bowman CN. The effect of cure rate on the mechanical properties of dental resins. Dent Mater 2001;17:504-11.

22. Willems G, Lambrechts P, Braem M, Celis JP, Vanherle G. A classification of dental composites according to their morphological and mechanical characteristics. Dent Mater 1992;8:310-9.

23. Sabbagh J, Ryelandt L, Bachérius L, Biebuyck J, Vreven J, Lambrechts P, et al. Characterization of the inorganic fraction of resin composites. J Oral Rehabil 2004;31:1090-101. 